\title{
Research on the Construction of Ideological and Political Teaching Team of College Courses Based on Competency
}

\author{
Nan Zhang $^{1}$ \\ ${ }^{1}$ Chongqing Aerospace Polytechnic (400021)
}

\begin{abstract}
Strengthening the construction of the ideological and political teaching team in the course of ideological and political teaching in colleges and universities can improve the level of ideological and political teaching in a certain degree. In the course of curriculum ideological and political implementation, there are new requirements for the various abilities of college teachers. Under this circumstance, teachers should study and analyze the construction of college curriculum ideological and political teaching team from the perspective of competency model based on curriculum ideology and politics. This article discusses the professional quality of ideological and political course teachers under the requirements of mastering the competency model and the relevant strategies for constructing the ideological and political teaching team of college courses. This article aims to improve the level of ideological and political teaching team building in colleges and universities.
\end{abstract}

\section{Introduction}

In the actual application process, the competency model needs to be combined according to specific job requirements to form a competency structure, which is the basis for carrying out human resource management and development practices. Companies can fully apply the competency model when conducting job analysis, talent recruitment, talent selection, talent training and development, and performance management. In the process of ideological and political teaching team building in colleges and universities, the application of competency model to analyze teaching team building strategies needs to start from the professional quality requirements of ideological and political teachers. This will help improve the ideological and political teaching ability, build a reasonable and scientific curriculum ideological and political teaching team, and improve the teaching level of ideological and political courses.

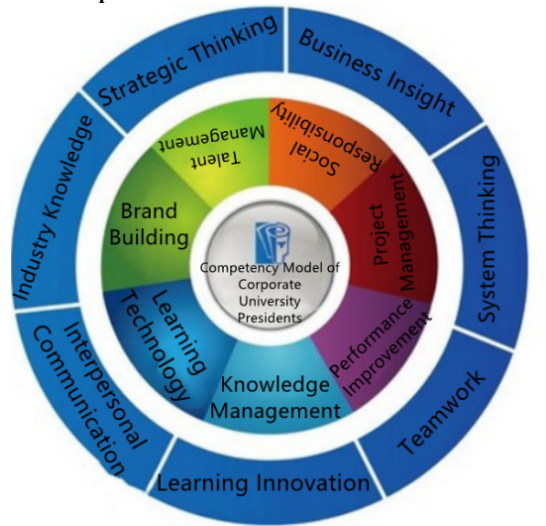

Fig 1 Competency Model

\section{The Significance of the Construction of Ideological and Political Teaching Team in Colleges}

Building an excellent teaching team in the course of ideological and political teaching in colleges and universities is an important foundation for improving the teaching level. The significance of excellent team building is mainly manifested in the following aspects. Firstly, the particularity of university organizations has relatively high requirements for flat teaching team organization. In the course of ideological and political teaching of college courses, the teaching work is carried out with knowledge tasks as the teaching center. In actual teaching, the connection between disciplines and colleges is mainly based on basic operation units, that is, basic work groups. The fundamental task of colleges and universities is to develop knowledge and teach and educate people. The high degree of professionalism of knowledge leads to loose connections between teachers and students. This will not only weaken the internal consistency of the university organization, but also weaken the order structure of the teaching organization. In consequence, there is an organized disorder in the current college teaching process. In this case, the curriculum ideological and political teaching will lead to a loose teaching system and affect the efficiency and level of curriculum ideological and political teaching. In order to improve the level of ideological and political teaching of courses, schools need to strengthen the construction of teaching teams. When constructing teaching teams, colleges and universities put more emphasis on the communication, coordination and 
cooperation between individual teachers in the team. It presents a relatively obvious flat characteristic, which is an important content to meet the requirements of the organizational characteristics of universities. This can not only give full play to the advantages of the loose joint system of the teacher team, but also overcome the disadvantages of the traditional ideological and political team that is too loose [2].

Secondly, in the rapid development of science and technology, the cooperation requirements between teachers are getting higher and higher. In the process of university teacher team building, the integration of disciplines has become an inevitable trend of teaching. The boundaries between various disciplines and categories in the field of science and technology have been broken, and the boundaries between the two major knowledge fields of science and technology and social science have also been impacted to a certain extent. Different subject theories or methods can penetrate and cross each other, thus forming a large number of interdisciplinary subjects. Meanwhile, the connection between technology and social economy is getting closer. Various problems in the process of social and economic development need to be tackled by multiple disciplines. Natural science issues such as the environment, energy, space, and ocean all require the participation of social sciences. The problems raised from the perspective of social science, such as urban development and social management, also require the application of mathematics and natural science technology. In this case, it is necessary to strengthen the communication and cooperation between the teacher team when carrying out the ideological and political teaching of college courses. In the meantime, colleges and universities should effectively integrate curriculum ideology and politics with students' professional disciplines. Only in this way can students create a good curriculum ideological and political teaching environment. Strengthening the construction of ideological and political teaching teams in colleges and universities can not only provide a platform for close cooperation between teachers, but also strengthen the communication and exchanges between the ideological and political teaching teams of the courses. Thirdly, the team building of teachers can greatly improve the effect and quality of ideological and political teaching. In the traditional course of ideological and political teaching, many teachers independently complete a number of tasks such as writing lesson plans, class teaching, tutoring and answering questions, and correcting homework. In this case, the professional ability of the ideological and political teachers of the curriculum will directly affect the teaching quality and effect of the ideological and political curriculum. However, with the comprehensive development of teaching content, teachers cannot be proficient in all aspects of professional knowledge when developing curriculum ideological and political teaching, especially in the development of modern information technology, which leads to more and more complicated teaching processes. If relying solely on the power of a single teacher, it is difficult to fully grasp all the knowledge of the curriculum ideological and political teaching content, and there will be some loopholes in the curriculum ideological and political teaching, which will affect the classroom teaching effect.
Building a team of teachers can give full play to the advantages of each teacher. In this way, ideological and political teachers can supplement the loopholes and deficiencies of teaching plans in cooperation and exchange, and show students the most cutting-edge and best knowledge content, thereby improving the quality and effect of curriculum ideological and political teaching. Especially under the guidance of the competency model, constructing a teaching team of ideological and political teachers can give play to the complementary advantages of team members. Team members continue to enrich their theoretical knowledge reserves in equal exchanges and promote the professional development of teachers. For example, in the process of teacher team building, the teacher team formed with famous teachers as the center can play the leading role of famous teachers and cultivate excellent curriculum ideological and political teaching teams [3].

\section{Problems in the Construction of Ideological and Political Teaching Team in Colleges}

At this stage, the main problems existing in the course of building the course ideological and political teaching team are manifested in the following aspects. Firstly, in the teaching team, the cooperation of teachers is relatively small, and there are still relatively serious individual combat problems. After years of development, under the influence of the university's ideology of advocating academic freedom, curriculum ideology has formed an education and teaching system with strong individuality and independence. At this stage, the ideological and political teaching of the curriculum is still centered on teachers. In addition to distinctive personal characteristics, many university teachers of ideological and political courses also have certain characteristics of group cooperation. Because the training of talents is systematic and complicated, it cannot be done by a single teacher, so colleges and universities need to strengthen cooperation between teachers to improve the effect of talent training. The cooperation between teachers in different research rooms, the coordination and cooperation between different course groups and disciplines can all improve the teaching effect of this major to a certain extent. But for a long time, the teaching ideology that overemphasizes the autonomy of the university individual has focused on the pursuit of personal value. This leads to in-depth cooperation between teaching teams in the development of curriculum ideological and political teaching. This will affect the effectiveness of the curriculum ideological and political teaching team building. Secondly, the structure of the teaching staff of ideological and political courses is unreasonable. When building a curriculum ideological and political teaching team, it is necessary to strengthen the cooperation and communication between personnel from different disciplines and from different schools of the same discipline. This enables teachers to absorb the excellent experience of others in teamwork, and form a unique teaching style according to their own teaching methods and teaching methods, thereby cultivating creative talents. 
Therefore, in the construction of the teaching team, the rationality of the structure of the teaching staff must be ensured and the source of the teaching staff must be expanded. Only in this way can we build a good teaching team and create a strong academic research atmosphere. Simultaneously, optimizing the teaching knowledge structure of ideological and political courses can promote the reform and innovation of teaching methods, and prevent teachers' teaching thoughts from being too single and closed during teaching activities. However, there is a serious problem of "inbreeding" in the current course ideological and political teaching team building process, and the concept of members absorbed by the teaching team is relatively uniform. This will make ideological and political teachers have the same thinking in teaching and scientific research, resulting in a relatively single and boring teaching method. Thirdly, colleges and universities pay more attention to scientific research in the process of curriculum ideological and political management system construction and ignore the improvement of teaching methods. In the development of colleges and universities, its fundamental task is to cultivate talents, and improving the quality of talent cultivation is an important foundation for school development. At this time, college teaching is the center of the school. However, when teachers deal with teaching and scientific research work, there are situations where they attach importance to scientific research and ignore teaching work. Especially in the evaluation of the school's teacher team management process and the evaluation of professional titles, more attention is paid to the teachers' scientific research ability and scientific research results, while the teachers' achievements in teaching are ignored. Some teachers with average teaching scores, but more scientific research achievements are more likely to be praised in the assessment. While focusing more on teaching, teachers with average scientific research achievements are at a disadvantage in the assessment and title evaluation. The teacher's assessment results are closely related to teacher bonuses and promotion titles. Under this faculty management system, teachers are more willing to devote more energy to scientific research rather than teaching. This will seriously affect the quality of university teaching. In order to solve this problem, colleges and universities need to strengthen the construction of teaching teams and build a high-level and professional curriculum ideological and political teaching team. This can lay the foundation for improving the quality of ideological and political teaching [4].

\section{Competence Model-Based Strategies for the Construction of Ideological and Political Teaching Teams in Universities}

\subsection{Improving the Professional Ability of Ideological and Political Teachers Based on Competency Model}

The fundamental task of ideological and political teachers is to make the trained talents meet the needs of social development. According to the competency model, colleges and universities divide the professional qualities of ideological and political teachers from personal traits and motivations, personal role positioning, self-cognition, and personal knowledge and skills these aspects. The professional quality requirements of ideological and political teachers include the following aspects. Firstly, the teacher's personal characteristics requirements. The state has increasingly higher requirements for ideological and political teachers in universities. General Secretary $\mathrm{Xi}$ Jinping has clearly pointed out in the National Ideological and Political Teachers Forum that to give full play to the key role of ideological and political teachers, colleges and universities must ensure that teachers have strong political requirements, new thinking, broad vision, strict selfdiscipline, and personality positive and deep feelings. The political requirement is the primary quality requirement of ideological and political teachers. When carrying out teaching activities, ideological and political teachers must strengthen the guiding position of Marxist ideology and strengthen the socialist ideology. The distinctive political nature in actual teaching determines that ideological and political teachers should learn and use, which is the main responsibility of ideological and political teachers. Therefore, in teaching activities, ideological and political teachers must establish a firm political stand and believe in Marxist thought and related theories. Only in this way can school teachers lead by example and spread Marxist ideas and related theories of socialism to students. Secondly, the requirements of colleges and universities on the knowledge literacy of ideological and political teachers. Because the logic and theory of ideological and political theory courses are relatively strong, teachers' professional knowledge and theoretical accomplishments will directly affect the quality of ideological and political teaching. In this case, it is necessary to strengthen the assessment of the knowledge literacy of ideological and political teachers. Ideological and political teachers must not only have a rich theoretical reserve of characteristic doctrine, but also have a relatively broad knowledge background and cultural heritage. They can grasp the teaching content of ideological and political courses from different angles and improve the teaching efficiency of ideological and political courses. At the same time, colleges and universities should strengthen the analysis and research on the frontier issues of Marxist theory when conducting research on Marxist theory, grasp the latest results of the Sinicization of Marxism, and keep pace with the times [5]. Thirdly, the ideological and political development of colleges and universities requires teachers' teaching ability. In the traditional ideological and political teaching process, the instillation teaching method is the main method. Compared with other courses, the ideological and political course itself is more abstract. If the instillation teaching method is still used, it will reduce the students' interest in learning and directly affect the teaching effect. In this case, teachers need to change teaching skills in time, innovate teaching methods, and optimize the way of teacher-student interaction in the teaching process. Meanwhile, teachers should transform boring theoretical knowledge so that students can understand and listen to it, thereby improving the efficiency and effectiveness of ideological and political teaching. When carrying out the teaching of ideological 
and political courses, teachers should focus on the cognitive laws of students, respect students' dominant position, and increase the appeal of teaching content. Teachers can use innovative teaching carriers in teaching methods to create a relatively good range of ideological and political learning for students. In particular, it is necessary to attach importance to integrating theory with practice so that students can realize the importance of studying ideological and political theories and related content. Only in this way can the teaching efficiency of ideological and political courses be improved and students can truly master the teaching theory of ideological and political courses.

\subsection{Strengthen the Team's Internal Construction Work}

In the process of building a teacher team, it is necessary to strengthen the team's internal construction work to build a reasonable-scale structure and a relatively complete teaching team. Especially under the influence of the competency model, universities need to fully grasp the professional quality requirements of the teacher team. Only in this way can the professionalism of the teaching team be improved. Universities can start from the following aspects to strengthen the team's internal construction work. Firstly, colleges and universities should choose good team leaders and give full play to the leading role centered on famous teachers. Colleges and universities should choose team leaders with relatively high levels and relatively strong abilities. Because the team leader is the organizer and builder of the team, he is the core staff of the curriculum ideological and political teaching team building. The team leader plays a vital leading and backbone role in the team. The academic level and organization and coordination ability of the leader will directly affect the quality of the construction of the teacher team. As a result, in the selection process of the leader of the ideological and political teaching team, teachers with broad academic vision and academic attainments should be selected. The leader must not only be able to grasp the development experience of the subject, but also love the teaching work of undergraduates. The leader should be able to master the specific learning needs of students, have rich teaching experience and superb teaching skills. In selecting leaders, colleges and universities need to conduct a comprehensive assessment of the teaching level of the leaders to ensure that the leaders are of excellent quality, high moral character, and have strong organizational management and leadership capabilities. This can improve the management level of the ideological and political teaching team. Secondly, universities must ensure the rationality of the team structure. In the process of ideological and political teaching team building, it is necessary to ensure that teachers' knowledge, skills, age, personality, and professional titles are complementary to a certain extent. Only in this way can the construction level of the teaching team be improved. In order to give full play to the guiding role of the teaching team to young teachers, the teaching team should pay attention to completing the construction of the teacher echelon and enhance the cohesion of the teaching team [6]. Thirdly, colleges and universities should use effective internal management and operating mechanisms to carry out teaching team management. In the construction of teaching teams, colleges and universities need to build a sound internal management and operation mechanism to effectively manage the teaching team. Only in this way can the teaching team continue to develop. Because the construction of the teaching team itself is a long-term work, universities must continue to accumulate and adjust to build a high-level teaching team. Colleges and universities can use clear activity rules within the team to strengthen communication and exchanges between teachers. Determining the activity time, location, content, teamwork methods, communication channels, and conflict handling principles can improve the efficiency of teaching team management and ensure good collaboration and development between teaching teams. Besides, colleges and universities should improve the team's operating foundation, and strengthen the construction of internal target incentives and competition incentive systems based on the leader's responsibility system. Especially the problems in teaching need to be discussed and learned regularly, and some major problems need to be resolved by the democratic consultation system. Universities should also pay attention to the young teacher training system and the team self-evaluation system. In the process of team operation, colleges and universities need to follow corresponding systems to improve the standardization and rationality of team building. Otherwise, colleges and universities should strengthen the connection with the student evaluation system in the process of teaching team building. In this way, the teaching situation of different teachers in the teaching team can be accurately evaluated, and the advantages and disadvantages in the course of ideological and political teaching can be clarified. Universities can also improve and innovate the work of the teaching team based on the evaluation results of the students, thereby building a teaching team with a relatively high professional level.

\section{Conclusion}

To sum up, in the current process of college curriculum ideological and political teaching team construction, it is necessary to use a competency model to fully grasp the basic quality requirements of college teachers. Simultaneously, it is also necessary to understand the construction strategy of the main teacher competence model based on the basic connotation of curriculum ideology and politics. Only in this way can we build a highlevel and professional curriculum ideological and political teaching team. Furthermore, the teaching team can take effective measures to improve the ideological and political teaching level of the curriculum according to the various problems existing in the current curriculum ideological and political teaching. Thereby, it can play the active role of the excellent teaching team in the curriculum ideological and political teaching. 


\section{References}

1. Zhang Jingchuan, Chu Heying, Kong Deguo, et al. Teaching team construction and practice research of college physics "curriculum ideological and political" $[\mathrm{J}]$. Educational Modernization, 2019, v.6(88):168-171+185.

2. Zhao Guang, Sun Weifeng, Zhong Jingyi. Research on the Construction of University Teachers' Competency Model from the Perspective of "Curriculum Ideological and Political" [J]. Nanjing Social Sciences, 2020(7).

3. Han Siqi, Shao Xin. Research on the construction of science and engineering teachers under the ideological and political system of college courses [J]. Science Popular, 2019, 000(003): P.173-174.

4. Yang Ping. Research on the Teaching Team Construction of Ideological and Political Courses in Colleges and Universities [J]. Cai Zhi, 2016, 000(022): 48-48, 50.

5. Wang Leiyu. On the path of strengthening the teaching team construction of ideological and political courses in colleges and universities[J]. Journal of Jiangsu Normal University of Technology, 2011, 17(5): 57-57.

6. Teng Yuemin, Han Feng. Construction path and strategy analysis of ideological and political collaboration education mechanism in college courses[J]. Journal of Shanxi Coal Management College, 2018, 031(006): 45-47. 